\title{
African NGO's and Womanism: Microcredit and Self-Help
}

\author{
Jane Duran
}

Published online: 8 October 2009

(C) The Author(s) 2009. This article is published with open access at Springerlink.com

\begin{abstract}
It is argued that womanism, a concept often associated with Black American women writers, is a driving force behind much of the activity of many West African cultures, including their current work with Non-Governmental Organizations (NGO's). The historical nature of womanism, both on the continent and in the Americas is addressed, and microcredit and NGO work in other areas held up to contrast. The conclusion is that women-oriented microcredit projects need to be seen through a specific cultural lens.
\end{abstract}

Keywords NGO's $\cdot$ Womanism $\cdot$ Microcredit $\cdot$ Economics

The growth of microcredit programs across the globe, and their impact on women and women's health and economic status, has been a focal point for much new research. The recent award of the Nobel Prize to the founder of one of the oldest programs in Bangladesh has helped to emphasize the difference that microcredit and the concept of self-help has made in women's lives. Nevertheless, it is also the case that very little of the reporting or research on such programs has emphasized feminist theory, the original status of women within the given culture, or the impact that that status might have on the establishment of such programs.

This paper argues that womanism, a concept often associated with Black American women writers, is a driving force behind much of the activity of many West African cultures, including their current work with NGO's. The historical nature of womanism, both on the continent and in the Americas is addressed, and microcredit and NGO work in other areas, such as parts of South Asia, held up to

J. Duran $(\bowtie)$

Department of Black Studies, University of California, Santa Barbara,

South Hall, Room 3631, Santa Barbara, CA 93106-3150, USA

e-mail: jduran@education.ucsb.edu 
contrast. The conclusion is that women-oriented microcredit projects need to be seen through a specific cultural lens.

Given that regional differences do and ought to have a role in the establishment of self-help programs, it can also be argued, as indicated, that there are feminist and feminist-oriented analyses of such programs that can be made, not only along the traditional lines of economic change, but also along less traditional lines of feminist epistemology (Duran 2001). Any feminist analysis must remain sensitive to important constructs from cultures that are not all on a par with each other with respect to indigenous patterns concerning women. It is especially the case, as recent work has shown, that misunderstandings abound about a number of African cultures, and the roles of women in such cultures (Oyewumi 1997). If it can be argued that the influence of NGO's in general is beneficial, it can also be argued that programs work best when they maintain a direct tie to women's cultural place, and that African programs have much to teach us in this regard.

Health programs involved with the AIDS crisis are often taken as exemplary of NGO work done in developing regions, and the Ugandan social scientist Christine Obbo has noted, with respect to that health issue in East Africa, that "It is taken for granted that women as wives, mothers, sisters and girlfriends...will look after the men, yet women are either neglected or encouraged by men to seek female relatives to look after them" (Obbo 1999, 159). Part of Obbo's larger point in the article is that there are a number of gender-related constructs at work in the greater Ugandan society that prevent caretakers, traditionally, from being male. Women, however well or ill, easily fall into the caretaker role, and any social group or organization that attempts to work with a situation in a Ugandan city, for example, will have to address these issues. As Obbo writes at the beginning of her piece:

AIDS has accentuated the tendency to create, join and maintain networks that are based on diverse interests such as work, religious inclinations, residential proximity and compatibility... [But] in the days of AIDS, a popular saying stresses, a man without a mother, sister or wife is doomed... (Obbo 1999, 153).

Although it might be argued that the tendency of microcredit programs - and the work of NGO's in general - to rely on women is more or less global, a good deal of what goes on in many African societies seems to reflect some gender-specific constructs of the societies in question. A number of African groups, both West and East African, have a long history of having women placed in the forefront of activity, inside or outside the home, and that history is one about which many Africans are prepared to testify. In other words, caretaking might not be thought to be the most important role here. Rather, there is a sense within a number of areas that women are achievers in ways that might not be possible in more Eurocentric cultures. Among the Yoruba and some other groups of the general Nigeria region, for example, a pattern of women engaging in trade and moving away from the home for long 
periods has resulted in a view that, according to many, does not match Western views of gender. ${ }^{1}$

If "womanism" may be thought to be a label describing a certain sort of Black feminism, it is clear that, historically speaking, this particular construct is old. This emphasis on the strength of women, particularly as seen from a West African point of view, also emerges in nineteenth-century commentary on the slave and slavederived Black cultures of the New World. As Angela Davis writes, one commentator in the nineteenth century noted that:

Required by the masters' demands to be as "masculine" in the performance of their
work as their men, Black women must have been profoundly affected by their
experiences during slavery... A traveler during that period observed a slave crew in
Mississippi returning home from the fields and described the group as including
forty of the largest and strongest women I ever saw together; ...they carried
themselves loftily, each having a hoe over the shoulder, and walking with a free,
powerful swing like chasseurs on the march (Davis 1983, 11).

Works of both non-fiction and fiction dealing with the Black New World cultures, the Black cultures of the United States in particular, detail the reliance of entire communities on the women in those communities. We may, in fact draw a line detailing the historical trajectory from the extant West African cultures of the slave trade to today's West African and West African-derived communities. Novels such as Gayl Jones' Corregidora and Gloria Naylor's Mama Day, and contemporary essays by Angela Davis, Kathleen Cleaver and others militate against the notion that it is possible to give an accurate depiction of Black history in the U.S. without relying heavily on women's role in that history. ${ }^{2}$ This notion of the historical strength of West African women would not be so important were it not for the fact that it flies in the face of the social construction of many microcredit and self-help programs across the globe. In other words, if we take as exemplary the programs of a certain region of South Asia, for example - and it is these regions that are often most frequently cited in the literature on such programs - we might think of such NGOdriven work as having difficulty getting off the ground because of the reluctance of males in the region to allow women to participate in the microcredit offerings. Martha Chen and others have written of the programs in Bangladesh that Western women who try to instantiate literacy classes are often viewed as "prostitutes" by the local mullahs, and that it is difficult to get women to participate because they so frequently have little say in decisions that are made about their lives (Chen 1983).

Thus the construction of NGO activity in any given area, and its effectiveness, is irretrievably affected by the position of women in the culture at large. Although this might on first construal seem obvious, it is clear that much that has been written about microcredit and self-help programs has failed to take this material into account. Thus, the comparative success of programs in Africa is due, in no small part, to the lives of African women and to their transparently important roles in the local communities.

\footnotetext{
${ }^{1}$ Oyewumi writes about this extensively, and it is indeed a leading thesis of her book.

${ }^{2}$ The fictional works draw on material from the African Diaspora in the New World and do so in a way that is revelatory.
} 
For purposes of contrast, the programs in Bangladesh-including that of Grameen Bank, which might be deemed to be the prototype - have often had to contend, as indicated above, with women's comparative lack of power in the region. Although until recently Bangladesh has been relatively unaffected by the varieties of Islam more prevalent in the Middle East, Bangladesh is an Islamic society, and it originally formed the Eastern part of the two-pronged state of Pakistan. ${ }^{3}$

The status of women in this Muslim locale has always revolved around the authority of male figures, be they husbands, brothers, or fathers. Chen's report that local mullahs often tried to discourage attempts by women to participate in literacy programs simply underscores that, for many women, leaving the home unaccompanied has always been bepurdah, or forbidden. Nevertheless, fighting back by a number of stratagems, including use of qiya, or argument by analogy, women in many rural Bangla villages have made great progress in the past two or three decades. ${ }^{4}$ One could readily claim, however, that these victories for Bengali women have not come easily, and that any attempt to alter their status in the community — or, indeed, within the home-has always come at a cost.

There is, then, an enormous difference between a society in which women have traditionally moved or worked outside of the home and one in which this is not the case. Even before Islam arrived in Bengal, the Hindu concepts of womanhood that had been propagated throughout the subcontinent by the Vedas and other commentary very much discouraged the notion that women could be accomplishers on their own. The male dominance of any given society is often difficult to discuss adequately or to discern in its totality, but the patriarchal structures of South Asia-reinforced by thousands of years of tradition, both written and oral - are among the oldest and most strongly established in the world. In Bangladesh, women often self-report the oppression to which they feel subjected by tradition, without specific advertence to any Western thinking, or, in many cases, to levels of formal education. Chen notes:

At one BRAC-organized workshop for women, the participants were asked to list their problems as women. They listed the following in no particular order:

- oppression by mothers-in-law

- differential feeding as a child

- no education

- no inheritance... (Chen 1983, 57).

The category "oppression by mothers-in-law" is especially interesting, as it is clear that what is visited upon one daughter-in-law (or daughter) later becomes visited by her upon someone else. The tradition is difficult to break, and the enforcedness of the tradition makes for hardships in the instantiation of any NGOdriven programs. Nevertheless, as Yunus reports and as many others have attested,

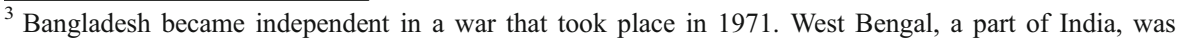
heavily affected by the displacements in the region during that conflict.

${ }^{4}$ Indeed, Muhammad Yunus, recent Nobelist for his work in this area, now claims that Bangladesh is gradually moving out of poverty, as defined by the U.N. and other international agencies.
} 
microcredit in Bangladesh works, and "phone ladies" and yogurt salespersons are ubiquitous. ${ }^{5}$ Although much of the work often proceeds initially against the will of local males - especially those who would label the assistance workers with hostile names - the majority of women in Bangladesh whose lives have been touched by the programs have been able to make changes in their lives.

If the claim can be made - as has been made by many - that an implicit part of the growth of women as persons through microcredit programs involves the development of a sense of competence and mastery along with the emergence of new skills, it could also be argued that these areas of growth will be more difficult to achieve and will be achieved with greater effort in societies like Bangladesh where the status of women has long been the subject of patriarchal discourse and dominance. Thus every effort made by aid workers in NGO programs, of whatever type, will involve major undertakings in Bangladesh, since part of the difficulty revolves around the notion of women functioning outside of a given space. Indeed, as Chen and others have shown, if the Qur'an is often cited in qiya argument by women to try to move their lives and the lives of their children in a different direction, mullahs and others will cite this document to opposite effect for counterargument in almost all instances (Cregg and Speight 1980).

Workers in the nations of West Africa, however, will generally not encounter similar difficulties, at least not in urban areas and in the non-Islamicized regions. Here the aid worker is likely to encounter cultural tropes that include women as marketpersons, sellers of goods, and movers-about. The women of urban regions of Nigeria, in particular, have a long history of being away from home for lengthy periods, and, indeed, traveling around the regions in which they live to conduct sales. If, as Oyewumi has argued, this entails a different view of gender constructs in West Africa, then this view needs to be taken into account in the sorts of endeavors, both policy-driven and on the ground, that are likely to take place on the African continent. The failure of workers to be able to articulate these differences is, obviously, an important omission.

\section{III}

If "womanism" may be defined as a Black feminist view that is community-oriented, as opposed to the sort of feminist view that has the privilege and luxury of defining oppression in terms of male dominance, it is also the case - as indicated earlier - that womanism has a history that may be documented in the United States back into the nineteenth century and, indeed, colonial times. Paula Giddings, in her When and Where I Enter, has noted that a womanist spirit pushed not only many of the moves made by slaves during the antebellum period, but more particularly the strivings made by the Black population after the Civil War and at the beginning of the twentieth century (Giddings 1984). Part of this is historical, and, as we have said, traces to the West African cultures that make up by far and away the largest portion of the populations of the African Diaspora. As Giddings writes:

Throughout their history, Black women also understood the relationship between the progress of the race and their own feminism. Women's rights were

\footnotetext{
${ }^{5}$ Yunus has given many public talks about his work, and has also authored popular books and articles.
} 
an empty promise if Afro-Americans were crushed under the heel of a racist power structure. In times of racial militancy, Black women threw their considerable energies into that struggle - even at the expense of their feminist yearnings (Giddings 1984, 7).

In other words, Black women were often propelled by a sense that Black progress rested on them, and that they could not waste effort in trying to obtain moves forward for themselves alone without expending the effort to make sure that the moves were all encompassing as far as race was concerned.

A number of historical documents from the preceding two centuries attest to the importance of the work of Black women for their community, and to the general strength of women of African ancestry in a slave-holding era. John Blassingame's Slave Testimony contains multiple citations to the lives of women slaves, and both the narrative of Olaudah Equiano and Walker's Appeal, while comparatively short on information about individual women, contain enough examples of acts of brutality that the nature of the obstacles facing the slave family is made clear. ${ }^{6}$ Elizabeth Keckley, in her Behind the Scenes, details not only her rise to freedom through her own earnings and purchasing power, but the fact that, after becoming a seamstress in the White House during the Civil War, she founded a school for young Black women in the area so that they could learn a similar skilled trade. The point of an analysis of "womanism," as opposed to the general feminist rubric, is to show how a community-oriented spirit that, again, derives from the cultural foci of West African societies pushes the activities of Black women in the New World so that an enormous difference may be noted between that which is merely feminist and that which is womanist. The Black woman has not had the luxury of being able to claim that she is oppressed as a woman and by males; the nature of her oppression has made it necessary for her to fight for her community at the same time that she fights for herself. And yet those who have made much of the crucial differences between feminism and womanism have often failed to note that womanism as a construct begins in those very matrilineal West African societies (particularly those of today's Ghana and Nigeria) that have an historical record of women having achieved in the general society at large.

\section{IV}

The history of microcredit - as opposed to more standard sorts of views of what would constitute economic growth for the poor - is well set-out in a piece by Susan Moller Okin (Okin 2002). Part of Okin's claim is that the emphasis on microcredit as a palliative effort is comparatively recent, and comes at the expense of traditional views. She writes:

In part because policy makers so often ignored gender considerations, the neoliberal policies ["structural adjustment," and policies of the International Monetary Fund and World Bank] described earlier failed to address adequately the problems of poor women in a number of ways. A great deal of the work

\footnotetext{
${ }^{6}$ Equiano's narrative contains multiple allusions to the "depredations" visited upon the "sable females"; Walker contends that the Black slaves in the Americas were the "most abject" persons in the history of humankind.
} 
women do-reproduction, housework, subsistence farming, and any work done in the family without pay-does not register in economic terms as "productive"...(Okin 2002, 285).

Microcredit takes the valuable insight that women's work is crucial to the functioning of any economy, and then attempts to address at least some of the needs of the poor through a use of women's time. Thus the yogurt sellers and "phone ladies" of Bangladesh have simply taken their craftwork (and, in some cases, housework-related) activities into a slightly broader marketplace or arena, and in so doing have often been able to signficantly alter village life.

Again the presence of strong women-oriented activities and structures within the culture, such as is the case in West Africa, makes an enormous difference in the ways in which the presence of microcredit groups and NGO's plays out. In Nigeria, a coalition of forces working with Greenpeace and other organizations was able to alter the stance of Shell. As Peter Newell has argued, activism there showed how "local incidents can soon develop into international crises." (Newell 2000, 38) Women have been active not only on an individual level, but also in setting up some of the NGO's themselves, regardless of the sphere of activity in which those NGO's operate.

In her recent acclaimed work, Political Theory and Feminist Social Criticism, Brooke Ackerly notes that, among others, "Women in Law and Development in Africa... [was] instrumental in developing inquiry through networking" before the Beijing UN Women's Conference (Ackerly 2000, 140-141). In addition, she cites with distinction the work of Rosemary Ofeibea Ofei-Aboagye, the Ghanaian theorist who has been at the forefront of work on domestic violence issues in West African nations (Ackerly 2000, 154). J. Oloka-Onyango is still another theorist engaged in such work. The point is, as has been recapitulated by many, that a tradition is in play that allows women from certain societies - that may in fact be matrilineal or matrifocal in their kinship structure - to propel themselves in a way that simply would not be possible, or even a topic of discussion, in other cultures. The upshot is that the work of these women is visible at every level, including the level of international organizations, the very groups that typically promote microcredit projects in the first place. Indeed, Ackerly cites Oloka-Onyango and a co-author as voicing the notion that women "feed into the evolution of international feminist theory" (Ackerly 2000, 202).

But if it is important to try to recapitulate differences between women's worldviews that allow for changes in the ways in which NGO's and microcredit agencies operate, it is also urgent to try to be clear about what sorts of differences all these distinctions can make on a theoretical level. In other words, if part of our task is to ask ourselves what the larger justification is behind NGO efforts, we need to become clearer on the difference that cultural difference makes.

Ackerly does just that when, throughout her work, she introduces the notion of an "everyday critic." Here the point is that women within a given culture, regardless of their level of formal education, are themselves critics. ${ }^{7}$ Among a variety of caveats and riders that Ackerly ultimately attaches to the notion of a social critic, she writes:

Social critics must follow a methodology intended to be sensitive to the reality of an imperfect world where power inequalities enable coercion and potential

${ }^{7}$ Chapter 1 of her work, 1-32, is titled "Silent Voices and Everyday Critics." 
exploitation to silence some within a society and to impede social criticism and social change (Ackerly 2000, 27).

As we have seen, within the distributory areas of microcredit projects, and given the reliance of such projects on women and women's work, it is important that the role of women within a local culture be given full examination. This is why it is crucial to articulate the notion that women in South Asia, for example, are facing a variety of obstacles and pressures that do not necessarily adhere to women in Ghana or Senegal. But a good deal of the literature that emanates even from the more successful international organizations leaves the reader with the impression that the hard work here has not been done. It is often the case that the articulation of the projects, their successes and their status within the hierarchy of such efforts, is described in such a way that the concept of "woman" is shoved under and unexamined general rubric.

Carolyne Dennis, in a piece in the volume edited by Jones and Nelson on poverty in urban Africa, is careful to note simply one aspect of gender in Ghana that is often overlooked, and that is relevant to NGO work in urban areas: kinship relations as they affect women (Dennis 1999). She writes:

In many African societies there are practices of rearing children which are usually defined in English as 'fostering'.... This is an inadequate and even mis-leading description of African practices.... The arrangements often vary for boys and girls... [with] girls being sent to older female relatives in order to learn the skills of a woman and to assist the receiving household with their labour (Dennis 1999, 127-128).

Dennis' ultimate point is that the geographic change in these practices from those of rural areas in the nation to urbanized areas has often led to a breakdown in the tradition, but the important part of her larger aim here is to acquaint the reader or researcher with the fact that some gender-related practices in Ghana may have pertinent implications for self-help, microcredit and NGO programs. Young girls who appear to be "on the street" in city areas of Northern Ghana may simply be living with older female relatives in an arrangement such as that described above, where the total household income is less than what it should be, and where the kinship structures are not as tightly woven as they might be in a village (Dennis 1999, 129). Whatever the accurate description, the notion that the young female may be of valuable assistance to the home in a variety of ways is an important one, and should not be lost sight of. It is, indeed, this sort of cultural pattern that needs to be examined in the promulgation of economic assistance programs.

I have been arguing that a sort of "womanism," in the tradition articulated by Black women writers of America and the African Diaspora in general, has infused a number of West African cultures, and is of the utmost importance in examining the history and functioning of microcredit programs in these nations. I have also asserted that other such programs, in other areas and geographic locales, contend with a much 
wider range of gender-linked practices, so that comparisons between the successes of such programs are odious without a better understanding of the role of gender within various societies. As Christina Nsekela has noted, "Conventional strategies such as the blue-print plans adopted by African countries for social welfare have...ignored the contribution of NGO's to national development..." (Nsekela 1998, 291).

If it is the case, as it currently seems to be, that a great deal of what is being accomplished internationally comes from NGO's rather than from governments, we need to look more closely not only at the individual NGO's, but at the cultural patterns that indicate whether or not they are successful. Ironically, much of the reporting on the "working" NGO's may stem from the South Asian nations precisely because - as we have seen, and as they themselves report-many of the groups within these nations struggle against an overwhelming tide of patriarchal values, and even the smallest move forward is an enormous victory, under the circumstances. For a woman in Bangladesh to be able to move around a village area, or even go from one village to another, whether it be with a cell-phone service or to sell fortified yogurt, is already a great victory in Bangla terms. The framework of cultures such as the Akan, Yoruba and Igbo, however, within such nations as Ghana and Nigeria has always been different, and even early reports from these societies indicate the differing status for women in those groups. Thus work that is accomplished in West Africa may not seem to be as worthy of note or report precisely because it is not achieved against such odds.

Jordan and Maloney argue in their Democracy and Interest Groups, "NGO's, in UN-speak, need to have aims and purposes in conformity with the spirit...of the UN Charter..." (Jordan and Maloney 2007, 30). They also note that the term "NGO" is itself a "hurrah" word. (Jordan and Maloney 2007, 30). Because NGO's are currently seen as in the forefront not only of human rights movements, but of efforts to try to instantiate globalization moves in an humane and caring way, anything having to do with the work of NGO's is now often celebrated and publicized. Since so many of the groups work largely with women - a fact known to all but seldom commented upon - the cultural tropes and levels of expectation that women in these groups must address on a daily basis need articulation. It is ironic that the matrilineal West African cultures, a source of commentary from the time of Olaudah Equiano on, are all too often left out of the catalog of successes and reportable stories associated with NGO's. If women within a given culture have a long history of trade and activity outside the home, it can be deemed to be a reliable source for growth and change when the time comes to establish a microcredit organization within the region. Unlike parts of India, Sri Lanka or Bangladesh, the struggle to start such a program may not require as great an effort as planned or forecast.

Equiano's Narrative, long a source of commentary on his Igbo people and their cultural background, notes that his is a nation of poets and dancers. He also notes that he holds the women of his culture in high regard. The activities and cultural structures of the West African societies need to be examined and forwarded in connection with any global analysis of microcredit. ${ }^{8}$ Genuinely helpful commentary on the economic programs of such regions cannot be made without an allusion to the historical status of women within the region.

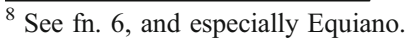


Open Access This article is distributed under the terms of the Creative Commons Attribution Noncommercial License which permits any noncommercial use, distribution, and reproduction in any medium, provided the original author(s) and source are credited.

\section{References}

Ackerly, B. (2000). Political theory and feminist social criticism. Cambridge: Cambrdige University Press. Blassingame, J. (1977). Slave testimony. Baton rouge: Louisiana State University Press.

Chen, M. A. (1983). A quiet revolution. Boston: Schenkman.

Cleaver, K. (2001). The black panthers and community. New York: Routledge.

Cregg, W., \& Speight, J. (1980). Islam from within. Belmont: Wadsworth.

Davis, A. Y. (1983). Women, race and class. New York: Vintage Books.

Dennis, C. (1999). Truck pushers, grain pickers and grandmothers: 'Street children' and some gender and age aspects of vulnerability in Tamale, Northern Ghana. In S. Jones \& N. Nelson (Eds.), Urban poverty in Africa (pp. 136-137). London: Intermediate Technology.

Duran, J. (2001). Worlds of knowing. New York: Routledge.

Equiano, O. (1994). The interesting narrative of Olaudah Equiano. New York: Viking.

Giddings, P. (1984). When and where $i$ enter. New York: Morrow.

Jones, G. (1998). Corregidora. Boston: Beacon.

Jordan, G., \& Maloney, W. A. (2007). Democracy and interest groups; Enhancing participation? Basingstoke: MacMillan.

Naylor, G. (1996). Mama day. New York: Viking.

Newell, P. (2000). Globalisation and the new politics of sustainable development. In J. Bendell (Ed.), Terms for endearment (pp. 31-39). Sheffield: Greenleaf.

Nsekela, C. M. K. (1998). Issues in social welfare; The role of NGO's. In A. K. Tibaijuka (Ed.), The social services crisis of the 1990's; Strategies for sustainable systems in Tanzania (pp. 291-294). Aldershot: Ashgate.

Obbo, C. (1999). Gender and urban poverty in the days of AIDS in Uganda. In Jones and Nelson (Eds.), Urban poverty (pp. 149-159).

Okin, S. M. (2002). Poverty, well-being and gender; what counts, who's heard? Philosophy \& Public Affairs, 31, 288-316.

Oyewumi, O. (1997). The invention of women. Minneapolis: University of Minnesota Press.

Walker, D. (1995). An appeal to the colored persons. New York: Hill and Wang. 